\title{
Pengaruh Model Pembelajaran Think Pair Share dan Motivasi Belajar terhadap Kemampuan Komunikasi Matematis Siswa Sekolah Menengah Pertama
}

\author{
Muhammad Abdi dan Hasanuddin \\ Pendidikan Matematika, Fakultas Tarbiyah dan Keguruan \\ Universitas Islam Negeri Sultan Syarif Kasim Riau \\ E-mail : abdireuss@gmail.com
}

\begin{abstract}
Abstrak. Penelitian ini bertujuan untuk menyelidiki pengaruh pembelajaran TPS dan motivasi siswa terhadap kemampuaan komunikasi matematis pada siswa SMP Negeri 4 Tambang. Penelitian ini merupakan penelitian quasi eksperimen. Subjek dalam penelitian ini adalah siswa kelas VIII-G dan kelas VIII-E SMP Negeri 4 Tambang dan objek penelitian ini adalah pengeeruh penerapan model pembelajaran Think Pair Share (TPS) terhadap kemampuan komunikasi matematis siswa yang ditinjau dari motivasi belajar. Teknik analisis data yang digunakan peneliti yaitu anova dua arah (two way anova). Instrumen yang digunakan adalah tes uraian untuk mengukur kemampuan komunikasi matematis siswa, dan angket untuk mengukur tingkat motivasi belajar siswa. Berdasarkan hasil penelitian disimpulkan bahwa (1) terdapat perbedaan kemampuan komunikasi antara siswa menggunakan model pembelajaran TPS dengan siswa menggunakan model pembelajaran konvensional (2) terdapat perbedaan motivasi belajar siswa kelas eksperimen dan kelas kontrol (3) terdapat kontribusi antara motivasi belajar dengan komunikasi metamatis. (4) tidak terdapat interaksi antara model pembelajaran dan motivasi siswa terhadap kemampuan komunikasi komunikasi matematis siswa. dengan demikian secara umum model pembelajaran TPS berpengaruh terhadap komunikasi matematis yang ditinjau dari motivasi belajar siswa SMP Negeri 4 Tambang.
\end{abstract}

Kata Kunci : TPS, Kemampuan Komunikasi Matematis, Motivasi Belajar,

\section{PENDAHULUAN}

Matematika merupakan ilmu universal yang mendasari perkembangan teknologi modern dan penting dalam berbagai disiplin ilmu serta mampu mengembangkan daya pikir manusia. Bagi dunia keilmuan, matematika memiliki peran sebagai bahasa simbolik yang memungkinkan terwujudnya komunikasi secara cermat dan tepat. Matematika sebagai salah satu ilmu yang harus dipelajari di setiap jenjang pendidikan mempunyai objek yang bersifat abstrak. Hal ini seharusnya bukan menjadi alasan bagi siswa untuk takut terhadap pelajaran matematika, tetapi justru menjadikan siswa tertantang untuk selalu mempelajarinya. Pembelajaran matematika yang ada di sekolah diharapkan menjadi suatu kegiatan yang menyenangkan. Melibatkan siswa secara aktif berkomunikasi dalam proses pembelajaran sehingga siswa tidak akan bosan dengan pembelajaran matematika.

Beberapa penelitian terkait dengan komunikasi matematika telah banyak dilakukan (Andriani \& Fitriani, 2016; Ariawan, 2016; Firmansyah, Hasanuddin \& Nelson, 2018; dan Meisya, Suhandri \& Nufus, 2018; dan Rahmayanti, Hasanuddin, \& Nelson, 2018). Selain itu, dalam NCTM disebutkan standar kemampuan yang seharusnya dikuasai oleh siswa sebagai berikut: (a) mengorganisasikan dan mengkonsolidasi pemikiran matematika dan mengkomunikasikan kepada siswa lain, (b) mengekspresikan ide-ide matematika secara koheren dan jelas kepada siswa lain, guru, dan lainnya, (c) meningkatkan dan memperluas pengetahuan matematika siswa dengan cara 
memikirkan pemikiran dan strategi siswa lain, dan (d) menggunakan bahasa matematika secara tepat dalam berbagai ekspresi matematika (Mahmudi, 2009, p. 2).

Faktanya kemampuan komunikasi matematis di Indonesia masih tergolong rendah. Hal ini di ketahui dari survey internasional The Trend International Mathematics and Science Study (TIMSS). Dari hasil survei internasional TIMSS pada tahun 2011, Indonesia berada di peringkat ke 38 dari 63 dalam pembelajaran matematika. Aspek yang dinilai dalam mtematika adalah pengetahuan tentang fakta, prosedur, konsep, penerapan pengetahuan dan pemahaman konsep. Menurut laporan hasil studi international 47\%. Jika dibandingkan dengan negara lain kemampuan Indonesia dalam menerjemahkan soal kedalam bahasa ide matematika diagram atau grafik ini masih berada dibawah rata-rata (TIMSS, 2011).

Sementara itu, hasil laporan Survei Programme for International Student Assesment (PISA) yang merupakan program organisasi kerjasama ekonomi dan pembangunan dunia (OECD) menunjukkan bahwa pada tahun 2009, prestasi siswa Indonesia berada pada posisi 68 dari 74 negara yang disurvei. Skor rata-rata kemampuan siswa di neara lainnya yaitu 496. Aspek yang dinilai dalam PISA adalah kemampuan pemahaman, pemecahan masalah, penalaran dan komunikasi (Gardenia, 2016).

Berdasarkan observasi pembelajaran matematika di SMP Negeri 4 Tambang, diperoleh keterangan bahwa pembelajaran pada umumnya bersifat konvensional. Tampak bahwa pembelajaran belum berpusat pada siswa (student centered learning). Siswa menerima materi yang disampaikan oleh guru secara aktif dengan mencatat dan hanya sedikit siswa yang mengajukan pendapat atau bertanya secara lisan terkait dengan materi tersebut. Jika mempelajari silabus dan Rencana Pelaksanaan Pembelajaran (RPP) yang digunakan dalam pembelajaran matematika di SMP Negeri 4 Tambang memang komponen-komponennya sudah mengacu pada KTSP. Akan tetapi, kejadian esensial yang ada di lapangan siswa masih berperan sebagai objek pembelajaran, belum sebagai subjek pembelajaran. Kurangnya kemampuan komunikasi matematika siswa itu dapat dilihat dari: 1) kurangnya kemampuan peserta didik dalam mengungkapkan ide-ide matematika ke dalam bentuk gambar dan grafik, 2) kurangnya ekspresi siswa dalam membuat model matematika, 3) rendahnya kemampuan menulis yaitu berupa kemampuan memberikan penjelasan secara matematika dengan bahasa yang benar dan mudah dipahami, 4) pada proses diskusi, hanya sedikit siswa yang mau berbicara dan cenderung adalah siswa yang itu-itu saja, 5) hanya sebagian kecil siswa yang berani menyampaikan penjelasan mengenai pertanyaan dari guru kepada teman-temannya, dan 6) pada akhir pelajaran siswa belum mampu membuat kesimpulan.

Berdasarkan permasalahan tersebut maka kemampuan komunikasi matematis siswa harus ditingkatkan. Supaya dapat terealisasi maka seorang guru harus berupaya untuk meningkatkan motivasi belajar siswa. Selain itu, tidak hanya motivasi belajar saja yang perlu ditingkatkan tetapi juga memperbaiki penggunaan strategi pembelajaran dalam proses pembelajaran matematika. Pada pembelajaran matematika, pendekatan yang sering digunakan adalah pendekatan konvensional, maka kegiatan proses belajar berpusat kepada guru. Kebiasaan bersikap pasif dan kurangnya motivasi dalam proses pembelajaran dapat mengakibatkan sebagian besar peserta didik takut dan malu bertanya pada guru mengenai materi yang kurang dipahami. Suasana belajar di kelas menjadi sangat monoton dan kurang menarik.

Perlu dirancang suatu pembelajaran yang membiasakan siswa untuk mengkonstruksi pemikirannya baik dengan guru, teman mau pun terhadap materi matematika itu sendiri. Salah satu cara yang dapat dilakukan untuk meningkatkan kemampuan komunikasi matematis siswa adalah dengan menerapkan model pembelajaran yang tepat. Cara lain yang dipandang tepat untuk mengembangkan kemampuan komunikasi matematik siswa adalah berdiskusi kelompok (Mahmudi,2009, p. 4 ). Diskusi kelompok memungkinkan memberikan kesempatan kepada siswa untuk mengkonstruksi pengetahuannya sendiri sehingga siswa lebih mudah untuk memahami konsep-konsep yang diajarkan dan mengkomunikasikan ide- idenya dalam bentuk lisan maupun 
tulisan. Salah satu alternatif untuk mendukung hal tersebut adalah dengan menerapkan model pembelajaran kooperatif.

Model pembelajaran kooperatif memiliki beberapa tipe. Salah satu tipe model pembelajaran kooperatif yang dapat mendorong partisipasi aktif siswadi dalam kelas adalah model pembelajaran kooperatif tipeTPS. Model pembelajaran kooperatif tipe TPS adalah salah satu tipe model pembelajaran kooperatif yang memberi kesempatan kepada setiap peserta didik untuk menunjukkan partisipasi kepada orang lain (Nataliasari, 2014).

Berdasarkan penelitian yang dilakukan oleh Husna dengan judul Peningkatan Kemampuan Pemecahan Masalah dan Komunikasi Matematis Siswa Sekolah Menengah Pertama Melalui Model Pembelajaran Kooperatif Tipe TPS. Hasil penelitian tersebut menunjukkan peningkatan kemampuan komunikasi matematis siswa dengan menggunakan pembelajaran kooperatif tipe TPS lebih baik dari pada siswa yang memperoleh pembelajaran konvensional (Husna dkk, 2013). Penelitian lain dilakukan oleh Yunita Ela Rizki dengan Judul Pengaruh Penerapan Model Pembelajaran TPS Terhadap Kemampuan Komunikasi Matematis Siswa. Hasil penelitian tersebut menunjukkan bahwa siswa menggunakan model pembelajaran kooperatif tipe TPS lebih baik dari pada siswa yang menggunakan pembelajaran konvensional (Rizki dkk, 2013). Penelitian lain juga dilakukan oleh Jenni Vitriani yang berjudul Pengaruh Penerapan Model Pembelajaran Kooperatif Tipe TPS Terhadap Kemampuan Komunikasi Matematika Siswa. Hasil penelian tersebut menunjukkan kemampuan komunikasi matematis siswa kelas VIII SMP Negeri 13 Padang Tahun Pelajaran 2013/2014 yang pembelajaran menggunakan model pembelajaran kooperatif TPS lebih baik dibandingkan dengan pembelajaran konvensional (Vitriani, 2014).

Irawan dalam Suprijono mengatakan bahwa dari tiga faktor yang mempengaruhi prestasi belajar yaitu latar belakang keluarga, kondisi atau konteks sekolah dan motivasi, maka faktor terakhir merupakan faktor yang paling baik. Welberg, dkk menyimpulkan bahwa motivasi merupakan kontribusi antara 11 sampai 20 persen terhadap prestasi belajar (Suprijono, 2014, p. 113). Perlu diingat pula bahwa pada setiap diri siswa terdapat motivasi belajar berneda-beda. Ada siswa yang mempunyai motivasi belajar tinggi dan ada pula yang memiliki motivasi belajar rendah. Oleh karena itu, setiap guru harus mampu memotivasi siswa dalam belajar agar motviasi yang pada masing-masing siswa tergugah secar optimal untuk meraih prestasi belajar.

Menurut Rasyad, motivasi berarti seni mendorong peserta didik untuk melakukan kegiatan belajar sehingga tujuan pembelajaran tercapai (Rasyad, 2006, p. 92). Pengertian ini sebetulnya lebih menekankan pada usaha guru untuk memberikan motivasi secara eksternal guna merangsang siswa agar lebih giat dalam belajar. Berdasarkan uraian tersebut menunjukkan bahwa motivasi mempunyai keterkaitan antara motivasi dengan hasil belajar siswa.

\section{METODE}

Penelitian ini merupakan penelitian quasi eksperimen dan desain yang digunakan adalah desain penelitian Nonequivalent Control Group Design. Subjek dalam penelitian ini adalah siswa kelas VIII-G dan kelas VIII-E SMP Negeri 4 Tambang dan objek penelitian ini adalah pengeeruh penerapan model pembelajaran TPS terhadap kemampuan komunikasi matematis siswa yang ditinjau dari motivasi belajar. Teknik analisis data yang digunakan peneliti yaitu uji-t, korelasi (Product Moment), dan anova dua arah (two way anova).

\section{HASIL}

Data yang diperleh yaitu motivasi siswa, kemampuan komunikasi matematika siswa dengan menerapkan pembelajaran kooperatif dengan model pembelajaran TPS pada kelas eksperimen dan dibandingkannya dengan hasil yang diperoleh oleh kelas kontrol. Berikut akan dijelaskan 
secara singkat mengenai korelasi pearson, uji homogenitas, uji normalitas, tes $t$ dan uji annova dua arahterhadap kelas eksperimen dan kelas kontrol.

\section{Kemampuan Awal (Pretest)}

Uji homogenitas yang peneliti lakukan terhadap hasil pretes yang peneliti lakukan sebelum memasuki pertemuan pertama pada materi pelajaran yang akan dilakukan penelitian yaitu materi prisma dan limas. Uji homogeniitas melakuakan uji varians terbesar dibanding varians terkecil yang menggunakan tabel $\mathrm{F}$. Setelah dilakuakn analisis menggunakan uji $\mathrm{F}$, diperoleh nilai $\mathrm{F}_{\text {hitung }}$ yaitu 1,49, sedangkan untuk nilai $F_{\text {tabel }}$ yaitu 1,88. Maka $F_{\text {hitung }}$ lebih kecil dari $F_{\text {tabel }}$. Dapat disimpulkan bahwa varians tersebut adalah homogen.

Selanjutnya, nilai pretest diolah dengan menggunakan rumus Liliefors untuk melakukan pengujian normalitas bagi kelas eksperimen dan kelas kontrol. Berdasarkan hasil analisis, diperoleh nilai $\mathrm{D}_{\text {hitung }}$ kelas eksperimen sebesar 0,094 , sedangkan untuk nilai $\mathrm{D}_{\text {tabel }}$ dalam taraf signifikansi $5 \%$ yaitu 0,257 . Maka $\mathrm{D}_{\text {hitung }}<\mathrm{D}_{\text {tabel. }}$ Dapat disimpulkan bahwa data kelas eksperimen berdistribusi normal. Selanjutnya untuk kelas kontrol diperoleh nilai $\mathrm{D}_{\text {hitung }}$ sebesar 0,121 , sedangkan untuk nilai $\mathrm{D}_{\text {tabel }}$ dalam taraf signifikansi $5 \%$ yaitu 0,253 . Karena $\mathrm{D}_{\text {hitung }}<\mathrm{D}_{\text {tabel, }}$ maka dapat disimpulkan data kelas kontrol berdistribusi normal. Setelah data kedua kelas dipastikan homogen dan berdistribusi nomal, maka dilanjutkan dengan melakukan anlisis dengan test-t terhadap nilai hasis tes kemampuan awal (pretes) untuk mengetahui bahwa data dari kedua kelas tidak memiliki perbedaan yang signifikan.

Berdasarkan hasil analisis tes- $t$ diperoleh nilai $\mathrm{t}_{0}=0,1199$. Dilanjutkan dengan menentukan df dengan rumus $\mathrm{df}=\mathrm{N}_{\mathrm{x}}+\mathrm{N}_{\mathrm{y}}-2=28+29-2=55$ dan dikonsultasi pada tabel nilai $\mathrm{t}_{\text {tabel }}$ pada taraf signifikan $5 \%$ di peroleh $t_{\text {tabel }}=2,00404$. Jadi dapat disimpulkan bahwa $t_{o}<t_{\text {tabel }}$, hal itu berarti benar bahwa tidak ada perbedaan kemampuan komunikasi matematika siswa antara kedua kelas. Setelah hasil tes kemampuan awal (pretes) kedua kelas sudah terbukti homogenitas, berdistribusi normal, dan tidak memiliki perbedaan, maka dapat dilanjutkan dengan memberikan perlakuan terhadap kelas eksperimen dan pembelajaran konvensional pada kelas kontrol.

\section{Kemampuan Akhir (Postest)}

Uji homogenitas yang dilakukan oleh peneliti adalah uji varians terbesar dibanding varians terkecil dengan menggunakan tabel F. Pengujian homogenitas yang peneliti lakukan adalah dari hasil tes kemampuan akhir (postes).

Berdasarkan analisis tersebut, diperoleh nilai $\mathrm{F}_{\text {hitung }}=0,81$, sedangkan nilai $\mathrm{F}_{\text {tabel }}=1,88$. Maka nilai $\mathrm{F}_{\text {hitung }}<$ nilai $\mathrm{F}_{\text {tabel }}$. Dapat disimpulkan bahwa varians tersebut adalah homogen. Selanjutnya dilakukan uji normalitas dengan Liliefors terhadap nilai kemampuan akhir (postes). Berdasarakan analisis uji normalitas tersebut, dapat diketahui bahwa nilai hitung Ks pada kelas eksperimen sebesar 0,1607, sedangkan besar nilai tabel Ks dengan signifikansi 5\% adalah sebesar 0,257. Karena $\mathrm{Ks}_{\text {hitung }}<\mathrm{Ks}_{\text {tabel }}$, maka dapat disimpulkan bahwa data berdistribusi normal. Selanjutnya untuk kelas kontrol diperoleh nilai $\mathrm{Ks}_{\text {hitung }}$ adalah sebesar 0,153, sedangkan untuk besar nilai $\mathrm{Ks}_{\text {tabe }}$ dengan signifikan 5\% adalah sebesar 0,253. Kerana $\mathrm{Ks}_{\text {hitung }}<\mathrm{Ks}_{\text {tabel }}$, maka dapat disimpulkan bahwa data berdistribusi normal.

Setelah memenuhi kedua syarat yaitu data harus homogen dan berdistribusi normal, dapat dilanjutkan dengan melakukan Test- $t$ terhadap hasil tes kemampuan akhir (postes). Berdasarkan hasil analisis test- $t$ diperoleh nilai $\mathrm{t}_{0}=2,696$. Dilanjutkan dengan menentukan $\mathrm{df}$ dengan rumus $\mathrm{df}$ $=\mathrm{N}_{\mathrm{x}}+\mathrm{N}_{\mathrm{y}}-2=28+29-2=55$ dan dikonsuldasikan pada tabel nilai $\mathrm{t}_{\text {tabel. }}$. Dengan $\mathrm{df}=55 \mathrm{dan}$ taraf signifikan 5\% di peroleh $\mathrm{t}_{\text {tabel }}=2,00404$.

Dengan demikian, $\mathrm{t}_{0}$ lebih besar dari $\mathrm{t}_{\text {tabel }}$ maka $\mathrm{H}_{\mathrm{a}}$ diterima dan $\mathrm{H}_{0}$ ditolak, yang berarti terdapat perbedaan antara variabel X dengan variabel Y. Kesimpulan adalah terdapat perbedaan kemampuan komunikasi matematika antara siswa yang menggunakan pembelajaran kooperatif 
dengan model TPS dengan kemampuan komunikasi matematika siswa yang menggunakan pembelajaran Konvensional. Hasil perhitungan selengkapnya dapat dilihat pada lampiran.

\section{Motivasi Belajar Siswa}

Uji homogenitas yang peneliti lakukan terhadap hasil angket motivasi belajar matematikas siswa. Uji homogeniitas melakuakan uji varians terbesar dibanding varians terkecil yang menggunakan tabel F. Setelah dilakuakan analisis menggunakan uji $F$, diperoleh nilai $F_{\text {hitung }}$ yaitu 0,80 , sedangkan untuk nilai $F_{\text {tabel }}$ yaitu 1,884. Maka $F_{\text {hitung }}$ lebih kecil dari $F_{\text {tabel. }}$. Dapat disimpulkan bahwa varians tersebut adalah homogen.

Selanjutnya dilakukan uji normalitas dengan Liliefors terhadap hasil angket motivasi belajar matematikas siswa. Berdasarakan analisis uji normalitas tersebut, dapat diketahui bahwa nilai hitung D pada kelas eksperimen sebesar 0,1403, sedangkan besar nilai tabel D dengan signifikansi $5 \%$ adalah sebesar 0,257 . Karena $\mathrm{D}_{\text {hitung }}<\mathrm{D}_{\text {tabel }}$, maka dapat disimpulkan bahwa data berdistribusi normal. Selanjutnya untuk kelas kontrol diperoleh nilai hitung D adalah sebesar 0,067, sedangkan untuk besar nilai tabel $\mathrm{D}$ dengan signifikan $5 \%$ adalah sebesar 0,253 . Kerana $\mathrm{D}_{\text {hitung }}<\mathrm{D}_{\text {tabel }}$, maka dapat disimpulkan bahwa data berdistribusi normal. Setelah memenuhi kedua syarat yaitu data harus homogen dan berdistribusi normal, dapat dilanjutkan dengan melakukan Test- $t$ terhadap terhadap hasil angket motivasi belajar matematika siswa. Berdasarkan hasil analisis test-t diperoleh nilai $\mathrm{t}_{0}=2$,81. Dilanjutkan dengan menentukan df dengan rumus $\mathrm{df}=\mathrm{N}_{\mathrm{x}}+\mathrm{N}_{\mathrm{v}}-2=28+29-2$ $=55$ dan dikonsuldasikan pada tabel nilai $\mathrm{t}_{\text {tabel }}$. Dengan $\mathrm{df}=55$ dan taraf signifikan $5 \%$ di peroleh $\mathrm{t}_{\text {tabel }}=2,00404$. Dengan demikian, $\mathrm{t}_{0}$ lebih besar dari $\mathrm{t}_{\text {tabel }}$ maka $\mathrm{H}_{\mathrm{a}}$ diterima dan $\mathrm{H}_{0}$ ditolak. Kesimpulan adalah terdapat perbedaan motivasi belajar matematika antara siswa yang menggunakan pembelajaran kooperatif dengan model TPS dengan motivasi belajar matematika siswa yang menggunakan pembelajaran Konvensional.

Korelasi Pearson yang peneliti lakukan terhadap hasil angket motivasi matematika siswa dengan kemampuan matematis siswa. Berdasarkan uji korelasi pearson pada kelas eksperiman dan kelas kontrol koefisien korelasi sebesar 0,65, dimana motivasi berkontribusi kuat terhadap kemampuan komunikasi matematis siswa dan besar sumbangannya yaitu 42,29\% dan sisanya $47,71 \%$ ditentukan oleh variabel lain. Dengan demikian dapat simpulkan bahwa adanya kontribusi yang kuat di berikan motivasi terhadap kemampuan komunikasi matematis siswa kelas eksperimen. Dengan demikian, Ha diterima dan Ho ditolak, yang berarti motivasi belajar matematika berkontribusi terhadap kemampuan komunikasi matematis siswa.

\section{Uji Anova Dua Arah}

Pengaruh motivasi dan model TPS terhadap hasil pembelajaran diperoleh $\mathrm{F}_{\text {hitung }}$ sebesar 1,108. Bila angka di konfirmasi dengan $\mathrm{F}_{\text {tabel }}$ dengan $\mathrm{dk} 2$ untuk pembilang dan 51 untuk penyebut, diperoleh angka 3,16 untuk taraf signifikan 0,05 (5\%), maka terlihat $\mathrm{F}_{\text {hitung }}<\mathrm{F}_{\text {tabel. }}$ Ini berarni hipotesi alternatif $(\mathrm{Ha})$ ditolak dan hipotesis nihil $(\mathrm{Ho})$ diterima. Kesimpulan adalah tidak terdapat interaksi antara model TPS terhadap kemampuan komunikasi matamatis ditinjau dari motivasi belajar siswa.

\section{PEMBAHASAN}

\section{Pengaruh Penerapan TPS Terhadap Kemampuan Komunikasi Matematis Siswa}

Untuk melihat apakah terdapat perbedaan kemampuan komunikasi matematika antara siswa yang menggunakan pembelajaran kooperatif dengan Model TPS dan siswa yang menggunakan pembelajaran konvensional dilakukan analisis menggunakan test $t$. Berdasarkan hasil analisis tersebut diperoleh hasil nilai $\mathrm{t}_{0}=2,696$, lebih besar dibandingkan nilai $\mathrm{t}_{\text {tabel }}$ untuk taraf signifikansi 5\% yaitu2,00404, maka dapat disimpukan bahwa terdapat perbedaan kemampuan komunikasi 
matematika antara siswa yang menerapkan pembelajaran kooperatif denga model TPS dengan siswa yang menerapkan pembelajaran konvensional.

Berdasarkan observasi selama proses pembelajaran berlangsung, model pembelajaran TPS ini mampu memunculkan keberanian siswa untuk tampil di depan kelas, menyelesaikan soal dan menjelaskannya secara sistematis kepada teman-teman siswa yang lainnya, siswa juga bersemangat untuk mencari solusi bersama pasangan kelompok dalam diskusi, sehingga memotivasi siswa untuk bisa lebih aktif dalam proses pembelajaran.

\section{Perbedaan Motivasi Belajar Kelas Eksperimen Dan Kelas Kontrol}

Selanjutnya untuk melihat apakah terdapat perbedaan motivasi belajar matematika antara siswa yang menggunakan pembelajaran kooperatif dengan Model TPS dan siswa yang menggunakan pembelajaran konvensional dilakukan analisis menggunakan test $t$. Berdasarkan hasil analisis tersebut diperoleh hasil nilai $\mathrm{t}_{0}=2,81$, lebih besar dibandingkan nilai $\mathrm{t}_{\text {tabel }}$ untuk taraf signifikansi $5 \%$ yaitu 2,00404, maka dapat disimpulkan bahwa terdapat perbedaan motivasi belajar matematika antara siswa yang menerapkan pembelajaran kooperatif dengan model TPS dengan siswa yang menerapkan pembelajaran konvensional.

\section{Besar Sumbangan Motivasi Terbadap Komunikasi Matematis Siswa}

Selain itu untuk melihat seberapa besar sumbangan motivasi belajar siswa terhadap komunikasi matematis antara siswa yang menggunakan pembelajaran kooperatif model TPS dan siswa yang menggunakan pembelajaran konvensional dilakukan analisis menggunakan kerelasi pearson. Berdasarkan hasil analisis, motivasi belajar matematika berkontribusi kuat terhadap kemampuan komunikasi matematis siswa, dimana motivasi menyumbangkan sebesar 42,29\% terhadap kemampuan komunikasi dan sisanya 47,71\% ditentukan oleh variabel lain.

\section{Interaksi Model TPS Terhadap Komunikasi Matematis Ditinjau dari Motivasi Belajar}

Selain itu untuk melihat adanya interaksi antara model TPS yang ditinjau dari motivasi belajar siswa terhadap hasil pembelajran diperoleh 1,108336861. Bila angka ini dikonfirmasi dengan $\mathrm{F}_{\text {tabel }}$ dengan $\mathrm{dk} 2$ untuk pembilang dan 51 untuk penyebut, diperoleh angka 3,16 untuk taraf signifikansi $0,05(5 \%)$, maka terlihat $\mathrm{F}_{\text {ratio }}>\mathrm{F}_{\text {tabel }}$. Ini berarti hiposesis alternatif $(\mathrm{Ha})$ ditolak dan hipotesis nihil (Ho) diterima. Dimana tidak terdapat interaksi model pembelajaran dan motivasi. Dengan kata lain kemampuan komunikasi matematis siswa karena pengaruh model pembelajaran tidak tergantung pada peringkat motivasi siswa dan komunikasi siswa karena pengaruh peringkat motivasi tidak tergantung pada model pembelajaran.

Beberapa hal yang perlu diperlu diperhatikan terkait pelaksaan pembelajaran TPS. Dalam tahap Think, guru sebaiknya memberi penguatan terhadap materi, agar kegagalan dan kesalahan dalam memperoleh materi tidak terjadi. Sedangkan, pada tahap Pair, guru hendaknya memaksimalkan waktu yang tersedia dalam membentuk kelompok. Pada tahap Share, guru hendaknya bersikap adil dalam mendistribusikan kesempatan kepada setiap kelompok. Penelitian ini hanya difokuskan pada kemampuan komunikasi matematis siswa, peneliti menyarankan untuk peneliti yang lain agar dapat meneliti terhadap kemampuan lain dari siswa, seperti kemampuan pemecahan masalah, penalaran, koneksi dan sebagainya. Masih terdapat siswa yang sulit berkerja sama baik kelompok. Sebaiknya guru selalu mengontrol siswa untuk berdiskusi agar siswa dapat berkerjasama dengan pasangannya dan saling membantu jika terdapat pasangan yang mengalami kesusahan. Model TPS membutuhkan alokasi waktu cukup lama, oleh karena itu sebaiknya guru membatasi jumlah permasalahan dan tingkat kesulitan suatu masalah yang harus diselesaikan oleh siswa dan tentunya juga harus disesuaikan dengan indikator serta tujuan pembelajaran. Pihak sekolah dapat memfasilitasi guru dalam mengunakan model pembelajaran TPS dalam pembelaran matematika. Untuk itu guru harus dapat membuat perencanaan yang seksama sehingga dapat 
meminimalkan jumlah waktu yang terbuang. Pihak sekolah hendaknya dapat memfasilitasi guru dalam mengunakan model pembelajaran TPS dalam pembelaran matematika, baik dari segi pelatihan maupun media pembelajaran.

\section{SIMPULAN}

Berdasarkan analisis data dapat diambil kesimpulan bahwa 1) Terdapat pengaruh pembelajaran kooperatif model TPS terhadap kemampuan komunikasi matematis siswa belajar menggunakan pembelajaran kooperatif model TPS dengan siswa menggunkan pembelajaran konvensional. 2) Terdapat perbedaan motivasi antara siswa menggunakan model TPS dengan siswa yang mengikuti pembelajaran konvensional. 3) Terdapat kontribusi motivasi siswa terhadap kemampuan komunikasi metematis. 4) Tidak terdapat interaksi antara model TPS terhadap komunikasi matematis ditinjau dari motivasi siswa. Model pembelajan TPS dapat dijadikan alternatif dalam pembelajaran di kelas. Riset ini hanya diterapkan pada materi prisma dan limas, jadi terbuka peluan untuk meneliti untuk materi lainnya.

\section{PENGHARGAAN}

Terima kasih kepada FTK UIN Suska Riau dan SMP Negeri 4 Tambang dan pihak lainnya yang telah membantu terlaksananya penelitian ini.

\section{DAFTAR PUSTAKA}

Andriani, M. dan Fitraini, D. 2016. Penerapan Strategi Think-Talk-Write untuk Meningkatkan Kemampuan Komunikasi Matematika Mahasiswa PGMI Semester II UIN Suska Riau, Suska Journal of Mathematics Education, 2(2), 117-124

Ariawan, R. 2016. Pengaruh Pendekatan Pembelajaran Visual Thinking Disertai Aktivitas Quick on the Draw untuk Meningkatkan Kemampuan Komunikasi Matematis Siswa. Suska Journal of Mathematics Education, 2(1), 20-30

Darkasyi, M. Johar, R dan Ahmad, A. 2014. Peningkatan Kemampuan Komunikasi Matematis dan Motivasi Siswa dengan Pembelajaran Pendekatan Quantum Learning pada Siswa SMP 5 Lhokseumawe. Jurnal Ditaktik Matematika. 1 (1), pp. 21-34.

Firmansyah, A, Hasanuddin, dan Nelson, Z. 2018. Pengaruh Model Pembelajaran Contextual Teaching and Learning terhadap Kemampuan Komunikasi Matematis Berdasarkan Pengetahuan Awal Siswa, Juring (Journal for Research in Mathematics Learning), 1(1), 1-10

Gardenia, N. 2016. Peningkatan Kemampuan Pemahaman dan Komunikasi Matematis Siswa SMP Melalui Pembelajaran Konsstruktivisme Model Needham. Jurnal Formatif, 6(2), 110118

Husna, Ikhsan, M. Dan Fatimah, S. 2013. Peningkatan Kemampuan Pemecahan Masalah Dan Komunikasi Matematis Siswa Sekolah Menengah Pertama Melalui Model Pembelajaran Kooperatif Tipe TPS, Jurnal Peluang, 1(2), 81-92

Mahmudi, A. 2009. Komunikasi Dalam Pembelajaran Matematika. Jurnal MIPMIPA UNHALU 8(1). 1-9

Meisya, S., Suhandri and Nufus, H. 2018. Pengembangan Lembar Kerja Siswa Berbasis ModelEliciting Activities untuk Memfasilitasi Kemampuan Komunikasi Matematis Siswa Sekolah Menengah Pertama. Juring (Journal for Research in Mathematics Learning), 1(1), 33-42

Nataliasari, I. 2014. Penggunaan Model Pembelajaran Kooperatif Tipe TPS untuk Meningkatkan Kemampuan Penalaran dan Pemecahan Masalah Matematis Siswa MTS. Jurnal Pendidikan dan Keguruan. 1(1). Artikel 3. 
Rahmayanti, K. R., Hasanuddin, dan Nelson, Z. 2018. Pengaruh Penerapan Metode Pembelajaran Aktif Modeling The Way terhadap Kemampuan Komunikasi Matematis Ditinjau dari Kemampuan Awal Siswa SMK Taruna Pekanbaru, Juring Journal for Research in Mathematics Learning), 1(1), 65-70

Rizki, Y.E., dkk. 2013. Pengaruh Penerapan Model Pembelajaran TPS Terhadap Kemampuan Komunikasi Matematis Siswa, Jurnal Pendidikan Matematika, 2(1), 37-44

TIMSS, Timss 2011 Internasional Result in Matematics, (Bostum: The International Center Boston College Lynch School of Education, 2011)

Vitriani, J. 2014. Pengaruh Penerapan Model Pembelajaran Kooperatif Tipe TPS Terhadap Kemampuan Komunikasi Matematika Siswa, Jurnal Pendidikan Matematika, 3(1), 45-49 